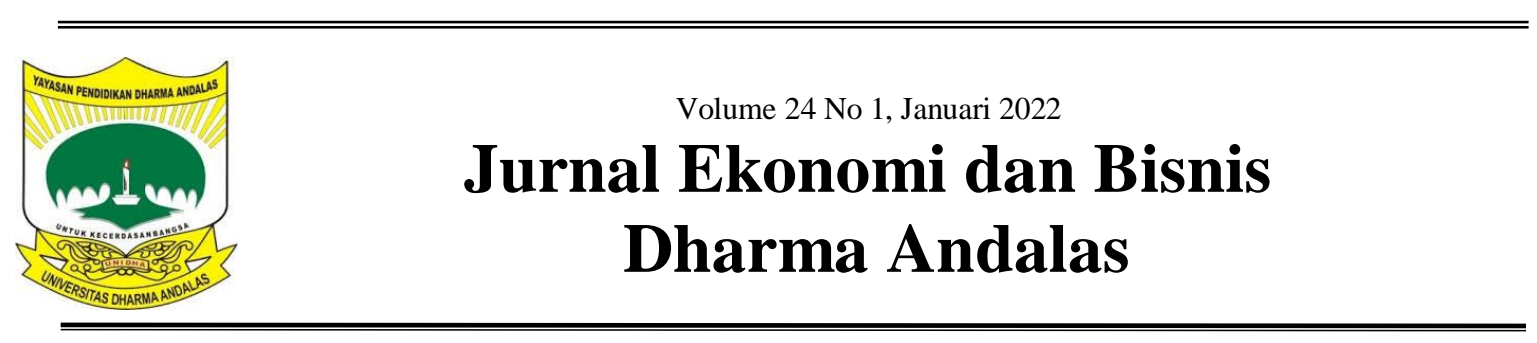

\title{
Transformasi Pendidikan Digital Mahasiswa FEB Universitas Dharma Andalas Saat Pandemi Covid 19
}

\author{
Anna Marina1 ${ }^{1}$, Nofri Yendra2 ${ }^{2}$ \\ Fakultas Ekonomi dan Bisnis Universitas Dharma Andalas ${ }^{1,2}$ \\ anna86marina@yahoo.com ${ }^{1}$ \\ nofriyendra84@gmail.com ${ }^{2}$
}

\begin{abstract}
The purpose of the study was to determine the effect of the use of smartphones, online learning systems and the use of Moodle on the learning achievement of FEB students at Dharma Andalas University partially and simultaneously during the covid 19 pandemic. 284 people was determined by a sampling technique of $20 \%$ of the population. Data collection techniques with documentation and survey studies use primary data in the form of questionnaires and secondary data through library research. All research variables meet the instrument test and classical assumption test, the results of the regression equation $Y=72,479+0.739 X 1+0.256 X 2+$ $0.437 X 3+e$. The results of the study show that the use of smartphones, online learning systems and the use of moodle have a significant positive effect on student achievement at a significance level of 5\%. The correlation between the use of smartphones, online learning systems and the use of Moodle with moderate learning achievement is 0.683. The use of smartphones, online learning systems and the use of Moodle were able to explain the learning achievement of FEB students at Dharma Andalas University 0.517, the remaining 48.33 were explained by other variables not included in the research model.
\end{abstract}

Keywords: learning achievement, smartphone, online, moodle

\begin{abstract}
ABSTRAK
Tujuan penelitian mengetahui pengaruh penggunaan smartphone, sistem pembelajaran daring dan penggunaan moodle terhadap prestasi belajar mahasiswa FEB Universitas Dharma Andalas secara parsial dan simultan saat pandemi covid 19. Populasi penelitian 1.132orang sampel 284 orang ditentukan dengan teknik pengambilan sampel $20 \%$ dari populasi. Teknik pengumpulan data dengan studi dokumentasi dan survei menggunakan data primer berupa angketdan data sekunder melalui library research. Semua variabel penelitian memenuhi uji instrumen danuji asumsi klasik, didapat hasil persamaan regresi $\mathrm{Y}=72.479+0.739 \mathrm{X}_{1}+0.256 \mathrm{X}_{2}+0.437 \mathrm{X}_{3}+\mathrm{e}$. Hasil pengujian hipotesis secara parsial dan simultan menunjukkan penggunaansmartphone, sistem pembelajaran daringdan penggunaan moodleberpengaruh positif signifikan terhadap prestasi belajar mahasiswa FEB Universitas Dharma Andalas pada tingkat signifikansi 5\%. Korelasi penggunaan smartphone, sistem pembelajaran daringdan penggunaan moodledengan prestasi belajar sedang 0.683. Penggunaan smartphone, sistem pembelajarandaringdan penggunaan moodlemampu menjelaskan prestasi belajar mahasiswa FEB Universitas Dharma Andalas 0.517 sisanya 48.33 dijelaskan oleh variabel lain tidak termasuk ke dalam model penelitian.
\end{abstract}

Keywords : prestasi belajar, smartphone, daring, moodle 


\section{PENDAHULUAN}

Seluruh satuan pendidikan termasuk perguruan tinggi di Indonesia harus melakukan pembelajaran daringdi rumah sehingga dunia pendidikan seolah mati suri meski kegiatan belajar mengajar masih berlangsung dengan bantuan teknologi karena pandemi covid 19 sejak Maret 2020. Teknologi tetap tidak dapat menggantikan peran guru/dosen dalam interaksi belajar mengajar sebab edukasi bukan hanya sekedar transfer knowledge tapi juga pembentukan karakter peserta didik. Pembelajaran daring mengharapkan peserta didik menjadi kompeten dengan keterampilan self directedlearningsebagai outcome edukasi. Kondisi social distancing dipandang tidak cukup melawan covid 19 justeru yang dibutuhkan social containment dalam skala besar (Long, 2020) sebagai intervensi pemerintah yang diterapkan ke seluruh komunitas kota/wilayah dirancang secara khusus untuk mengurangi interaksi pribadi kecuali interaksi minimal untuk memastikan pasokan vital (Smith dan Freedman, 2020). Pembelajaran daring butuh smartphone untuk menambah ilmu pengetahuan yang berdampak terhadap prestasi belajar sebagai keberhasilan usaha yang dicapai seseorang setelah memperoleh pengalaman belajar (Winkel, 1987).

Prestasi belajar sebagai output dari sistem pembelajaran daring menggunakan smartphone belum efektif karena dari aspek kognitif, afektif dan psikomotor tidak bisa diukur memaksa shifting dalam pola dan metoda pembelajaran di berbagai negara termasuk Indonesia dengan berbagai kesulitan pembelajaran. Kelebihan pembelajaran daring, peserta didik bisa menghemat waktu dan biaya ke sekolah (kampus). Kelemahannya sulit mengontrol peserta didik yang serius mengikuti pelajaran karena daya tangkap peserta didik berbeda, lebih banyak bersifat teoritis dan minim praktek karena tidak memungkinkan adanya interaksi langsung pendidik dengan peserta didik. Fenomena lain yang terjadi gagapnya pendidik dan peserta didik menggunakan teknologi informasi komunikasi, orang tua stres karena harus selalu mendampingi anak-anaknya belajar di rumah dan anak bingung menghadapi tumpukan tugas yang harus dikumpul sesuai deadline yang relatif pendek.

Sejak Mendikbud mengeluarkan Surat Edaran No. 36962/MPK.A/HK/2020 tanggal 16 Maret 2020 seluruh kegiatan belajar mengajar di seluruh satuan pendidikan dengan metode daring sebagai upaya pencegahan perkembangan dan penyebaran pandemi covid 19 melalui platform yang telah tersedia seperti moddle sebagai kelas virtual yang mempertemukan pendidik dan peserta didik. Di dalamnya tersedia folder yang berisi tugas, materi dan ruang diskusi. Belajardaring menjadi tuntutan pendidikan beberapa tahun terakhir ( $\mathrm{He}$ dkk, 2014) dengan memanfaatkan teknologi informasi (Panigrahi dkk, 2018) pelaksanaannya berlansung dengan koordinasi antara semua pihak (Tolsteneva dkk, 2019) sehingga tercipta pendidikan tinggi dengan lingkungan belajar modern (Huda, et.al, 2018). Belajar daring bukan suplemen yang hanya bermanfaat tambahan (Williams dkk, 2012) karena belajar daring bukan informal yang tidak terstruktur seperti dalam kehidupan sehari-hari saat orang mengakses internet (Holland, 201) dengan mengarahkan segala sumber daya untuk terciptanya pendidikan daring tahun 2025 (Palvia, et.all, 2018).

Kebijakan pembelajaran daring menimbulkan beragam respon dari kalangan dosen dan mahasiswa dengan berbagai masalah yang dihadapi sbb : 1) 
Masalah jaringan, 2) Sulit bertemu untuk mendiskusikan materi belajar, 3) Pemborosan kuota internet, 4) Mahasiswa ada yang tidak mempunyai smartphone. Untuk menerapkan kebijakan belajar dari rumah (Darmalaksana dan Corona Hadis, 2020) butuh kepemimpinan solutif sebagai tuntutan abad 21 yaitu pemimpin strategis (Mihardjo dan Rukman, 2018) menuntut pemimpin transformasional pro inovasi sesuai kebutuhan pengguna (Farahnak dkk, 2019).

Aplikasi pembelajaran daring diakomodir sesuai Permendikbud No. 22 / 2016 tentang Standar Proses Pendidikan Dasar dan Menengah berhubungan dengan pemanfaaatan ICTdengan 4 pilar pendidikan menurut UNESCO sbb : learning toknow, learning to do, learning to be dan learning to live together. Saat pandemi covid 19 melanda Indonesia merupakan kesempatan paling tepat untuk kembali mengajarkan learning how to learn bukan learning whatto learn termasuk kepada mahasiswa FEB Universitas Dharma Andalas seperti tabel 1.

Tabel 1.

Jumlah Mahasiswa Aktif Fakultas

Ekonomi dan Bisnis Universitas

Dharma Andalas Semester Genap

Tahun 2020 / 2021

\begin{tabular}{lc}
\hline \multicolumn{1}{c}{ Prodi } & Jumlah (Orang) \\
\hline S1 Manajemen & 515 \\
D3 Manajemen & 106 \\
S1 Akuntansi & 278 \\
D3 Akuntansi & 233 \\
\hline \multicolumn{2}{c}{ Total } \\
\hline
\end{tabular}

Sumber :ICT Unidha, 2021

Persoalan lain pembelajaran daring saat pandemi covid 19 sbb : 1) Perlu persiapan jauh hari untuk semua perangkat dan bahan termasuk kurikulum tapi persiapan tersebut selama ini tidak pernah ada/diantisipasi sehingga para pendidik mengalami goncangan teknologi, 2) Perlu perangkat teknologi gadget, jika satu keluarga memiliki banyak anak yang tersebar di semua jenjang pendidikan sementara penghasilan keluarga terbatas sehingga akan sangat memberatkan, 3) Kurikulum yang ada secara nasional hanya disiapkan untuk sistem pembelajaran konvensional sehingga Tujuan Instruksional Khusus yang sudah disusun menjadi kurang tepat/hilang, 4) Penguasaan teknologi belum merata dari tingkat Sekolah Dasar sampai Perguruan Tinggi karena belum semua pendidik menguasai aplikasi program yang diperlukan. Sehubungan dengan pembelajaran daring perlu pengembangan e-university untuk mendukung penyelenggaraan pendidikan sehingga perguruan tinggi dapat menyediakan layanan informasi yang lebih baik kepada komunitasnya (Pujilestari, 2020).

Menurut mahasiswa dan dosen pembelajaran daring menggunakan smartphone dan moodle tidak efektif dan efisiensi meskipun smartphone memiliki kemampuan mengakses internet dan aplikasi lainnya (Alnas, 2015). Pembelajaran daring fokus menggunakan internet dalam pendidikan sebagai solusi pendidikan dan peserta didik tidak dapat hadir secara fisik ke setiap pertemuan proses pembelajaran (Rusman, 2012). Wabah pandemi covid 19 telah merubah tatanan dunia pendidikan menjadi pembelajaran daring diprediksi akan berdampak terhadap prestasi belajar termasuk mahasiswa FEB Universitas Dharma Andalas sehingga perlu dilakukan riset tentang metode pembelajaran daring.

Berdasarkan uraian di atas rumusan masalahpenelitian :Bagaimanakah prestasi belajar mahasiswa FEB Universitas Dharma Andalas dilihat dari penggunaan smartphone, sistem pembelajaran 
daringdan penggunaan moodlesecara parsial dan simultan saat pandemi covid 19 ?Tujuan penelitian mengetahui prestasi belajar mahasiswa FEB Universitas Dharma Andalas dilihatdari penggunaansmartphone,sistem pembelajaran daring dan penggunaan moodlesecara parsial dan simultan saat pandemi covid 19.

Smartphone merupakan telepon genggam dengan kemampuan sangat tinggi menyajikan fitur canggih dan lengkap dibandingkan handphone sebagai pembaharuan perkembangan teknologi komunikasi (Yu, 2013). Menurut

(www.businessdicyionary.com)

smartphone is mobile phone which includesfunctions similarti those found on personal computers. Smartphones provide a one stop for information maangement, mobile calls, email sending and internet access. Smartphone are compact insize and often onlyslightly bigger than standar mobile telephones. A populer smartphone device is the blackberry. Jenis smartphone sesuai bentuknya (Edi, 2005) sbb : 1) Handphone, 2) iPhone, 3) Tablet, 4) iPad, 5) iPod, 6) Smartwatch, 7) iWatch. Model pembelajaran daring muncul untuk merespon perkembangan dunia teknologi informasi komunikasi yang sangat pesat saat ini sebagai perangkat yang melekat dalam proses pembelajaran (http://alisadikinwear.wordpress.com/20 12/07/07/mobile-learning-m-learningsolusi-cerdas-pembelajaran-terkini).

Pembelajaran daring tidak sepenuhnya bisa menggantikan elearning karena pembelajaran daring memiliki keterbatasan dari sisi perangkat sbb :1) Kemampuan prosesor, 2) Kapasitas memori, 3) Layar tampilan, 4) Catu daya, 5) Perangkat I/O. Manfaat smartphone sebagai media pembelajaran sbb : 1) E-learning, 2) E-book, 3) Situs pencarian sangat membantu mencari informasi/materi pembelajaran, 4) Sebagai media sosial untuk pembelajaran.Hal yang mempengaruhi seseorang menggunakan aplikasi dan fitur yang terdapat dalam smartphone(Asmani, 2011) sbb : 1) Mengikuti perkembangan zaman, 2) Untuk lebih aktif di media sosial, 3) Mempermudah kegiatan sehari-hari.

Perkembangan teknologi pendidikan mempermudah model pembelajaran (Lantip dan Rianto, 2011) sebagai ilmu pengetahuan di bidang pendidikan berbasis komputer menggunakan ICT (Lantip \& Rianto, 2011) dengan fungsi ICT (Abdulhak, 2005) sbb : 1) Sebagai media pendidikan ; 2) Sebagai sumber informasi ; 3) Sebagai sistem pembelajaran. Moodle(modular object oriented dynamic learning environment) sebuah paket perangkat lunak untuk membuat pendidikan berbasis internet sehingga tercipta pembelajaran dinamis, mengutamakan orientasi objek untuk mendukung kerangka konstruksi sosial dalam pendidikan. Moodle dibangun dengan pendekatan sosial konstruktiv untuk kegiatan pendidikan diintegrasikan dengan sistem/teknologi lain yang diperlukan (Despotovi at all, 2012 \& Rice, 2011). Moodle dikembangkan oleh (Martin Dougiamas, 2002) sebagai paket perangkat lunak untuk membuat latihan soal dan lainnya berbasis internet sebagai pengembangan platform moodle guna memudahkan membuat tampilan sistem aplikasi manajemen pembelajaran online berbasis web. Platform learning moodle memakai model computer assisted learning dan komputer assisted teaching. Pengembangan media e-learning moodle mengacu pada model prosedural define,design, develop dan disseminate dengan indikatornya sbb : 1) Kelengkapan materi ; 2) Kejelasan bahasa yang digunakan ; 3) Kelengkapan 
isi media ; 4) Kejelasan bahasa pada soal ; 5) Kemudahan mengoperasikan media ; 6) Ketertarikan pada tampilan media ; 7) Video pembelajaran ; 8) Rasa senang menggunakan media ; 9) Motivasi dalam belajar ; 10) Minat dalam menggunakan media pada materi lain (Thiagarajan, et.all, 1974).Kelebihan pemakaian moodle sbb : 1) Cocok untuk diterapkan dalam kelas online dapat diakses oleh siapa saja ; 2) Keamanannya terjamin ; 3 ) Menyediakan aneka macam bahasa bagi pengguna ; 4) Bersifat open source software ; 5) Memiliki manajemen kursus ; 7) Menyediakan modul chat bot ; 8) Perangkatnya sederhana, kompatibel, ringan dan efisien. Terdapat 7 lapisan user sbb : 1) Administrator ; 2) Course creator ; 3) Teacher ; 4) Non editing ; 5) Student ; 6) Guestenrolment key dan komunitas e-learning ; 7) Authenticated user. Variasi platform learning moodle sbb : 1) moodle.com. ; 2) moodle.org.website ; moodlecloud.com.

Fitur penting pada sistem elearning moodle sesuai fungsi dan kegunaannya sbb : 1) Personalized dashboard ; 2) Progress tracking menggunakan course completion, grades, badges, activity completion,competencies ; 3) File management ; 4) Peer assement ; 5)Inline feedback ; 6) Multimedia integration.

Pelaksanaan SPADA (Sistem Pembelajaran Daring) sesuai Permendikbud No.109/2013 memakai bantuan audio, video dan perangkat komputer/kombinasi dari ketiganya (Munir, 2009) sebagai strategi/metode pembelajaran paling efektif mampu menjangkau tempat yang sangat luas dengan biaya relatif murah dengan menawarkan 3 program sbb : 1) Materi terbuka ; 2) Materi kuliah terbuka ; 3 ) Mata kuliah daring.

$$
\text { Kelebihan sistem }
$$

pembelajaran daring (Rusman \& Cepi,
2011) sbb : 1) Tersedianya fasilitas emoderating ; 2) Pendidik dan peserta didik dapat menggunakan bahan ajar/petunjuk belajar terstuktur dan terjadwal melalui internet ; 3) Peserta didik dapat mereview bahan belajar setiap saat dimana saja jika diperlukan ; 4) Bila peserta didik butuh tambahan informasi berhubungan dengan materi pembelajaran dapat mengaksesnya dengan mudah di internet ; 5) Pendidik dan peserta didik dapat melakukan diskusi melalui internet ; 6) Berubahnya peran peserta didik dari pasif menjadi aktif dan lebih mandiri ; 7) Relatif lebih efisien bagi mahasiswa yang tinggalnya jauh dari sekolah/perguruan tinggi. Kekurangan sistem pembelajaran daringsbb : 1) Kurangnya interaksi antara pendidik dan peserta didik ; 2) Cenderung mengabaikan aspek psikomotorik ; 3) Proses pembelajaran cenderung ke arah pelatihan ; 4) Peran pendidik berubah dari pembelajaran konvensional kepembelajaran berbasis ICT ; 5) Peserta didik cenderung tidak mempunyai motivasi belajar tinggi ; 6) Jumlah tenaga terampil yang mengoperasikan internet dan menguasai bahasa pemrograman komputer kurang. Salah satu instrumen untuk mengevaluasi kualitas objek pembelajaran berupa LORI (LearningObject Review Instrument) dirancang sebagai instrumen untuk menilai kualitas objek pembelajaran multimedia dengan butir-butirnya seperti tabel 2 (Nesbit dan Leacock, 2004).

Tabel 2.

Kriteria Butir Instrumen Dalam LORI

\begin{tabular}{|c|c|c|}
\hline No. & Kategori & Deskripsi \\
\hline 1. & Kualitas konten & $\begin{array}{l}\text { Kebenaran, akurasi, keseimbangan } \\
\text { penyajian ide dan ketetapan tingkat } \\
\text { kerincian (keluasan dan kedalaman). } \\
\text { Dalam evaluasi objek pembelajaran, } \\
\text { aspek kualitas konten merupakan } \\
\text { elemen paling menonjol dalam } \\
\text { membentuk kepakaran. Objek } \\
\text { pembelajaran meskipun desainnya }\end{array}$ \\
\hline
\end{tabular}




\begin{tabular}{|c|c|c|}
\hline No. & Kategori & Deskripsi \\
\hline
\end{tabular}

2. Keselarasan dengan tujuan pembelajaran

3. Umpan balik dan adaptasi

4. Motivasi

6

Usabilitas interaksi

7. Aksesabilitas

8. Reusabilitas

Objek pembelajaran dikembangkan sebagai pendukung kegiatan pembelajaran. Oleh karenanya evaluasi atas objek pembelajaran harus mencakup keselarasannya dengan tujuan pembelajaran, aktivitas belajar, asesmen dan karakteristik peserta pembelajaran. Objek pembelajaran menjadi kurang efektif bila ternyata tidak selaras dengan kegiatan belajar dan asesmennya.

Pemberian umpan balik dan adaptasi objek pembelajaran terhadap karakteristik peserta pembelajaran merupakan salah satu cara untuk mengefektifkan pembelajaran.

Kemampuan objek pembelajaran untuk memotivasi dan menarik perhatian peserta pembelajaran Kualitas motivasi objek pembelajaran mempengaruhi besarnya upaya peserta pembelajaran untuk belajar dengan objek pembelajaran tersebut.

5. Desain presentasi

Desain informasi visual dan auditif untuk memperkuat pembelajaran dan meningkatkan efisiensi pemrosesan informasi. Desain presentasi merujuk pada kualitas eksposisi sumber belajar digital.

Konsep usabilitas interaksi diadopsi dari fitur kualitas perangkat lunak. Kemudahan navigasi, keintuitifan antar muka pengguna dan kualitas antar muka untuk pemberian bantuan merupakan fitur-fitur yang dinilai dari aspek usabilitas interaksi.

Desain kendali dan format presentasi untuk mengakomodasi peserta pembelajaran berkebutuhan khusus dan yang mengakses bahan ajar melalui pekerjaan bergerak

Potensi untuk digunakan dalam berbagai konteks pembelajaran dan berbagai latar belakang peserta pembelajaran.

Kepatuhan Kepatuhan terhadap standar terhadap standar internasional dan spesifikasi standar yang diikuti.

Sumber : Nesbit dan Leacock, 2004.

Objek pembelajaran yang dipasang dalam LMS perilaku navigasi dan antar muka pengguna sepenuhnya ditentukan oleh rancangan LMS. Evaluator cukup mengevaluasi kualitas pembelajaran daring yang dengan menetapkan 4 standar acuan seperti tabel 3.

\section{Tabel 3}

\section{Standar Acuan Pembelajaran Daring}

\begin{tabular}{|c|c|c|}
\hline No. & Kategori & Deskripsi \\
\hline 1. & Konten & $\begin{array}{l}\text { Evaluasi standar konten meliputi : 1) } \\
\text { tujuan pembelajaran, 2) silabus atau } \\
\text { rencana pembelajaran, 3) tujuan } \\
\text { pembelajaran, 4) } 4 \text { persyaratan } \\
\text { pembelajaran, 5) isu terkait hak cipta } \\
\text { HAKI, 6) kebijakan tentang proteksi data, } \\
\text { 7) assesmen pembelajaran, 8) konten } \\
\text { pembelajaran yang akurat dan mutakhir, 9) } \\
\text { literasi informasi umum dan keterampilan } \\
\text { komunikasi, 10) tersedianya sumber } \\
\text { belajar, 11) catatan dan sumber belajar }\end{array}$ \\
\hline 2. & $\begin{array}{l}\text { Desain } \\
\text { pembelajaran }\end{array}$ & $\begin{array}{l}\text { Evaluasi desain pembelajaran meliputi : } \\
\text { 1) rancangan pembelajaran, 2) paket } \\
\text { pembelajaran, 3) unit pembelajaran, 4) } \\
\text { keterlibatan pembelajar, 5) penugasan } \\
\text { tertulis, 6) perancangan konsep } \\
\text { pembelajaran yang tahan lama, 7) } \\
\text { pembelajaran aktif, 8) alur belajar } \\
\text { alternatif, 9) paket pembelajaran, 10) } \\
\text { adaptasi pembelajaran, 11) interaksi } \\
\text { pembelajar dengan fasilitator } \\
\text { pembelajaran, 12) pembelajar memiliki } \\
\text { akses terhadap informasi dan bahan ajar, } \\
\text { 13) umpan balik terhadap isi pembelajaran }\end{array}$ \\
\hline 3. & Asesmen & $\begin{array}{l}\text { Evaluasi asesmen meliputi : 1) strategi } \\
\text { asesmen konsisten dengan tujuan } \\
\text { pembelajaran, 2) struktur paket } \\
\text { pembelajaran mencakup metode dan } \\
\text { prosedur, 3) assesmen formatif dilakukan } \\
\text { untuk memverifikasi kesiapan pembelajar } \\
\text { mengikuti tahap pembelajaran berikutnya, } \\
\text { 4) strategi asesmen menjadikan } \\
\text { pembelajar menyadari kemajuan } \\
\text { belajarnya, 5) strategi asesmen cukup } \\
\text { fleksibel untuk mengakses pembelajar } \\
\text { dalam beragam cara, 6) skema dan model } \\
\text { pemeringkatan tersedia untuk mengakses } \\
\text { pembelajar }\end{array}$ \\
\hline 4. & Teknologi & $\begin{array}{l}\text { Evaluasi teknologi meliputi : 1) } \\
\text { paksitektur pembelajaran, 2) } \\
\text { pembelajaran disusun sesuai } \\
\text { interoperabilitas teknis, 3) } \\
\text { pembelajaran } \\
\text { pembet } \\
\text { aksesabilitas, 4) kebutuhan spesifikasi } \\
\text { perangkat keras dan perangkat lunak, 5) } \\
\text { persyaratan keterampilan teknologi, 6) } \\
\text { bantuan teknis penyedia paket } \\
\text { pembelajaran }\end{array}$ \\
\hline
\end{tabular}

Sumber : NHS Shared Learning, 2019.

Prestasi belajar adalah tingkat keberhasilan yang dicapai peserta didik setelah mengikuti kegiatan pembelajaran dimana tingkat keberhasilan ditandai dengan skala nilai berupa huruf/kata/simbol (Dimyati dan Mudjiyono, 2009). Prestasi belajar adalah penguasaan 
pengetahuan/keterampilan yang dikembangkan oleh mata pelajaran ditunjukkan dengan nilai tes/angka/nilai yang diberikan (Risa, 2005). Prestasi merupakan hasil dari kegiatan yang telah dikerjakan sebagai keberhasilan peserta didik dalam memahami materi, tingkat penguasaan materi, perubahan emosional/perubahan tingkah laku diukur dengan tes tertentu, diwujudkan dalam bentuk nilai/skor setelah menempuh proses pembelajaran (Djamarah, 1994) juga dapat dinyatakan dalam kalimat yang mencerminkan hasil yang sudah dicapai peserta didik (Fathurohman dan Sulistyorini, 2012). Hakikat prestasi belajar merupakan kemampuan yang diperoleh peserta didik setelah melalui kegiatan belajar dan belajar itu sendiri sebagai proses seseorang untuk memperoleh bentuk perilaku yang relatif menetap (Mulyono, 2003).

Faktor lain yang mempengaruhi prestasi belajar (Muhibbin, 2014) seperti gambar 1.

Faktor intern serta motivasi dalam meraih prestasi (Slameto, 2010).

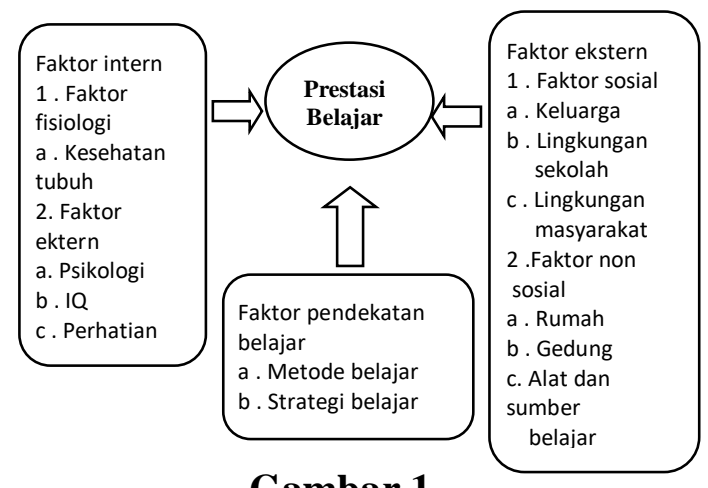

Gambar 1.

\section{Faktor-Faktor yang Mempengaruhi} Prestasi Belajar

Indikator prestasi belajar berfungsi sebagai penunjuk adanya prestasi tertentu yang hendak diukur sehingga pemilihan penggunaan alat evaluasi akan menjadi lebih tepat, reliabel dan valid (Muhibbin, 2014). Prestasi belajar mencakup kemampuan kognitif, afektif dan psikomotor peserta didik (Agus, 2010) dengan indikatornya seperti tabel 4.

Tabel 4

Indikator Prestasi Belajar

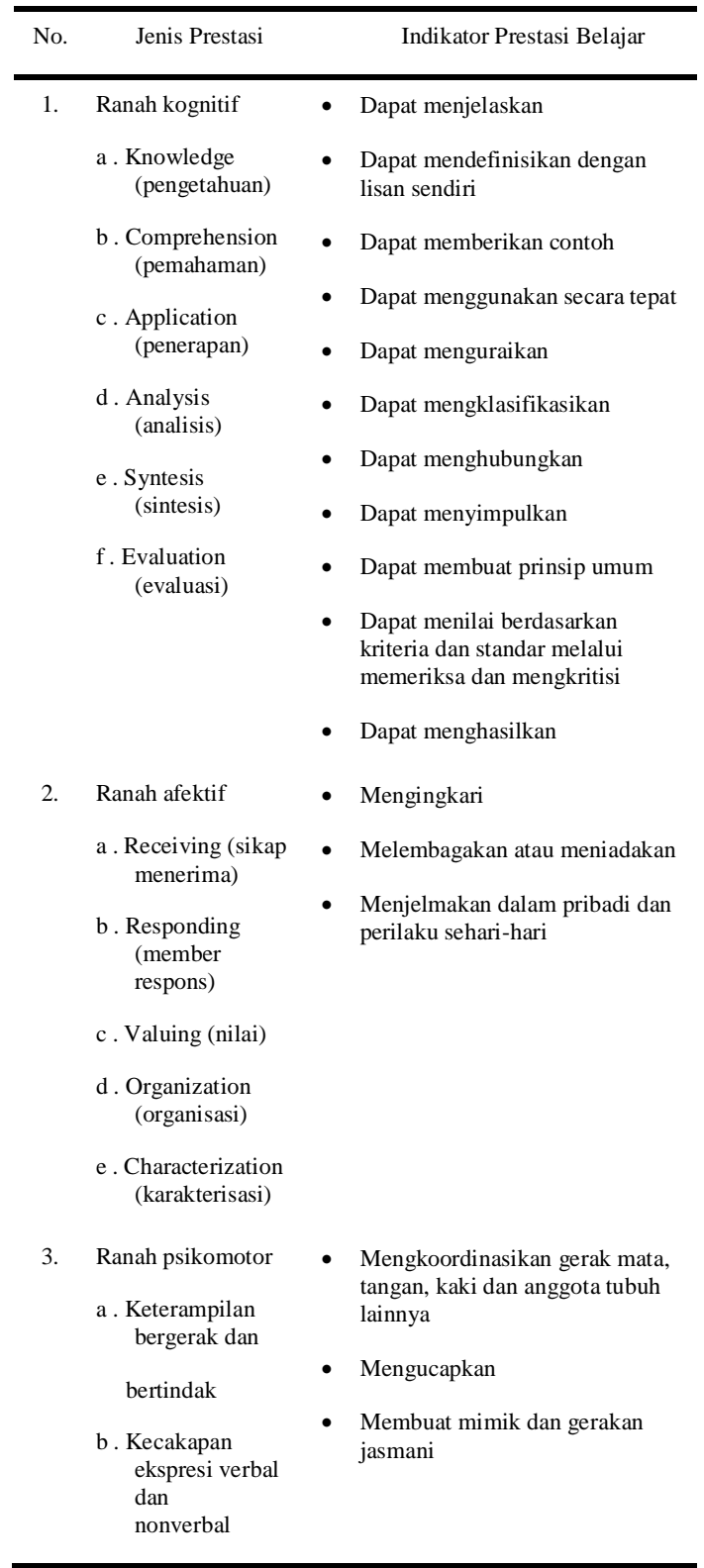

Sumber : Agus, Suprijono, 2010.

Indikator lain prestasi belajar (Mulyasa, 2006) seperti tabel 5 :

Tabel 5.

Indikator Prestasi Belajar dan Cara Evaluasi Cara Evaluasi 


\begin{tabular}{|c|c|c|c|}
\hline \multirow[t]{2}{*}{ A. } & $\begin{array}{l}\text { Ranah kognitif } \\
\text { 1. Pengamatan }\end{array}$ & $\begin{array}{l}\text { 1. Dapat menunjukkan } \\
\text { 2. Dapat } \\
\text { membandingkan } \\
\text { 3. Dapat } \\
\text { menghubungkan }\end{array}$ & $\begin{array}{l}\text { 1. Tes lisan } \\
\text { 2. Tes tertulis } \\
\text { 3. Observasi }\end{array}$ \\
\hline & 2. Ingatan & $\begin{array}{l}\text { 1. Dapat menyebutkan } \\
2 \text {. Dapat menunjukkan } \\
\text { kembali }\end{array}$ & $\begin{array}{l}\text { 1. Tes lisan } \\
\text { 2. Tes tertulis } \\
\text { 3. Observasi }\end{array}$ \\
\hline & 3. Pemahaman & $\begin{array}{l}\text { 1. Dapat menjelaskan } \\
\text { 2. Dapat } \\
\text { mendefinisikan }\end{array}$ & $\begin{array}{l}\text { 1. Tes lisan } \\
\text { 2. Tes tertulis }\end{array}$ \\
\hline & 4. Aplikasi & $\begin{array}{l}\text { 1. Dapat memberikan } \\
\text { contoh } \\
\text { 2. Dapat } \\
\text { menggunakan } \\
\text { secara tepat }\end{array}$ & $\begin{array}{l}\text { 1. Tes tertulis } \\
\text { 2. Pemberian } \\
\text { tugas } \\
\text { 3. Observasi } \\
\text { 1. Tes tertulis }\end{array}$ \\
\hline & 5. Analisis & $\begin{array}{l}\text { 1. Dapat menguraikan } \\
\text { 2. Dapat } \\
\text { mengklasifikasikan }\end{array}$ & $\begin{array}{l}\text { 2. Pemberian } \\
\text { tugas }\end{array}$ \\
\hline & 6. Sintesis & $\begin{array}{l}\text { 1. Dapat } \\
\text { menghubungkan } \\
\text { materi- } \\
\text { materi sehingga } \\
\text { menjadi kesatuan } \\
\text { baru } \\
\text { 2. Dapat } \\
\text { menyimpulkan } \\
\text { 3. Dapat membuat } \\
\text { prinsip umum }\end{array}$ & $\begin{array}{l}\text { 1. Tes tertulis } \\
\text { 2. Pemberian } \\
\text { tugas }\end{array}$ \\
\hline B. & $\begin{array}{l}\text { Ranah afektif } \\
1 . \text { Penerimaan }\end{array}$ & $\begin{array}{l}\text { 1. Menunjukkan sikap } \\
\text { menerima } \\
\text { 2. Menunjukkan sikap } \\
\text { menolak }\end{array}$ & $\begin{array}{l}\text { 1. Tes tertulis } \\
\text { 2. Tes skala } \\
\text { sikap } \\
\text { 3. Observasi }\end{array}$ \\
\hline & 2. Sambutan & $\begin{array}{l}\text { 1. Kesediaan } \\
\text { berpartisipasi / } \\
\text { terlibat } \\
\text { 2. Kesediaan } \\
\text { memanfaatkan }\end{array}$ & $\begin{array}{l}\text { 1. Tes skala } \\
\text { sikap } \\
\text { 2. Pemberian } \\
\text { tugas } \\
\text { 3. Observasi }\end{array}$ \\
\hline & 3. Apresiasi & $\begin{array}{l}\text { 1. Menganggap } \\
\text { penting dan } \\
\text { bermanfaat } \\
\text { 2. Menganggap indah } \\
\text { dan harmonis } \\
\text { 3. Mengagumi }\end{array}$ & $\begin{array}{l}\text { 1. Tes skala } \\
\text { sikap } \\
\text { 2. Pemberian } \\
\text { tugas } \\
\text { 3. Observasi }\end{array}$ \\
\hline & 5. Penghayatan & $\begin{array}{l}\text { 1. Mengakui dan } \\
\text { meyakini } \\
2 \text {. Mengingkari } \\
\begin{array}{l}\text { 1. Melembagakan } \\
\text { atau meniadakan } \\
\text { 2. Menjelmakan } \\
\text { dalam pribadi dan } \\
\text { perilaku sehari-hari }\end{array}\end{array}$ & $\begin{array}{l}\text { 1. Tes skala } \\
\text { sikap } \\
\text { 2. Pemberian } \\
\text { tugas } \\
\text { tentang sikap } \\
\text { dan ramalan }\end{array}$ \\
\hline C. & $\begin{array}{l}\text { Ranah psikomotor } \\
\text { 1. Keterampilan } \\
\text { bergerak dan } \\
\text { bertindak }\end{array}$ & $\begin{array}{l}\text { Kecakapan } \\
\text { mengkoordinasikan } \\
\text { gerak mata, tangan, } \\
\text { kaki dan anggota tubuh } \\
\text { lainnya }\end{array}$ & $\begin{array}{l}\text { 1. Observasi } \\
\text { 2. Tes } \\
\text { tindakan }\end{array}$ \\
\hline & $\begin{array}{l}\text { 2. Kecakapan } \\
\text { ekspresi verbal }\end{array}$ & & $\begin{array}{l}\text { 1. Tes lisan } \\
\text { 2. Observasi }\end{array}$ \\
\hline
\end{tabular}

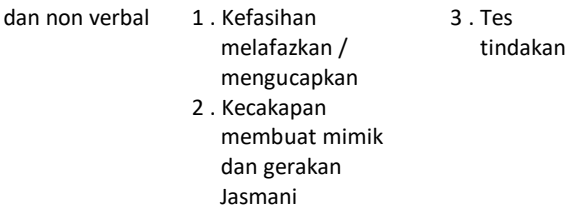

Sumber : (Mulyasa, 2006)

Hipotesis merupakan dugaan sementara peneliti untuk menjawab tujuan penelitian dengan hipotesisnya didugapenggunaaan smartphone, sistem pembelajaran daring dan penggunaan moodle berpengaruh positif signifikan terhadap prestasi belajar mahasiswa FEB Universitas Dharma Andalas secara parsial dan simultansaat pandemicovid 19 seperti gambar 2.

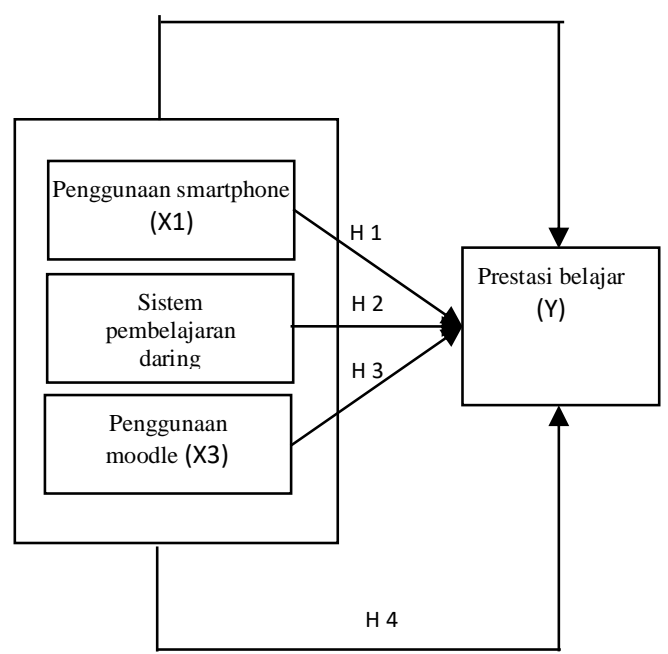

Gambar 2

Hipotesis Penelitian

\section{METODE PENELITIAN}

Pendekatan penelitian bersifat kuantitatif expost facto yaitu penelitian untuk meneliti peristiwa yang telah terjadi kemudian merunut ke belakang melalui fenomena untuk menentukan faktor penentu sebab yang mungkin terhadap peristiwa yang diteliti (Sugiyono, 2015) dan pendekatan kuantitatif menggunakan angka mulai dari pengumpulan data, penafsiran data dan penampilan hasilnya (Suharsimi, 2010). 
Populasi adalah wilayah generalisasi yang terdiri atas subjek/objek yang mempunyai kualitas dan karakteristik tertentu yang diterapkan oleh peneliti untuk dipelajari kemudian ditarik kesimpulan (Sugiyono, 2015). Populasi penelitian 1.132 orang semua mahasiswa FEB Universitas Dharma Andalas aktif semester genap 2020 / 2021. Sampel adalah sebagian dari populasi yang diteliti (Suharsimi, 2010) dengan ketentuan bila subjek penelitian kurang dari 100 sebaiknya diambil sampel diambil secara total sampling. Tapi bila subjek penelitian banyak maka sampel diambil 10\% - 15\% atau 20\% $25 \%$ bisa juga lebih dengan teknik stratifiedrandom sampling. Jumlah sampel penelitian sebanyak 284 orang seperti tabel 6.

\section{Tabel 6.}

\section{Sampel Penelitian}

\begin{tabular}{ccccc}
\hline No. & $\begin{array}{c}\text { Program } \\
\text { Studi }\end{array}$ & $\begin{array}{c}\text { Jumlah } \\
\text { Mahasiswa }\end{array}$ & Sampel & $\begin{array}{c}\text { Jumlah } \\
\text { Sampel }\end{array}$ \\
\hline 1. & $\begin{array}{c}\mathrm{S}_{1} \\
\text { Manajemen }\end{array}$ & 515 orang & $25 \%$ & $\begin{array}{c}129 \\
\text { orang }\end{array}$ \\
2. & $\begin{array}{c}\mathrm{D}_{3} \\
\text { Manajemen }\end{array}$ & 106 orang & $25 \%$ & 27 orang \\
3. & $\mathrm{S}_{1}$ Akuntansi & 278 orang & $25 \%$ & 70 orang \\
4 & $\mathrm{D}_{3}$ Akuntansi & 233 orang & $25 \%$ & 58 orang \\
\hline & Total & 1.132 orang & - & 284 \\
& & & orang
\end{tabular}

Sumber : ICT Universitas Dharma Andalas,

2021.

Jenis dan sumber data dalam penelitian ini berupa data primer dikumpulkan dengan melakukan pengamatan secara langsung terhadap mahasiswa FEB Universitas Dharma Andalas menggunakan angket dan data sekunder dikumpulkan dari library research.

Instrumen penelitian terdiri dari variabel bebas penggunaansmartphone (X1), sistem pembelajaran daring (X2), penggunaanmoodle(X3) dan prestasi belajar (Y) seperti tabel 7

\section{Tabel 7.}

\section{Blue Print Instrumen Penelitian}

\begin{tabular}{|c|c|c|}
\hline Dimensi & Indikator & Pengukuran \\
\hline $\begin{array}{l}\text { Penggunaan } \\
\text { smartphone }\left(\mathrm{X}_{1}\right) \\
\text { adalah aktifitas yang } \\
\text { dilakukan untuk } \\
\text { berkomunikasi dan } \\
\text { berinteraksi } \\
\text { menggunakan fitur- } \\
\text { fitur yang ada pada } \\
\text { smartphone seperti } \\
\text { akses internet }\end{array}$ & $\begin{array}{l}\text { 1.Pengetahuan } \\
\text { pengetahuan } \\
\text { smartphone } \\
\text { 2.Fungsi smartphone } \\
\text { 3.Kelebihan } \\
\text { smartphone } \\
\text { 4. Kekurangan } \\
\text { smartphone } \\
\text { 5. Motivasi } \\
\text { menggunakan } \\
\text { smartphone } \\
\text { 6. Umpan balik } \\
\text { penggunaan } \\
\text { smartphone }\end{array}$ & $\begin{array}{l}\text { Angket } \\
\text { dengan } \\
\text { skala Likert } \\
(1-5)\end{array}$ \\
\hline $\begin{array}{l}\text { Sistem pembelajaran } \\
\text { daring }\left(\mathrm{X}_{2}\right) \text { adalah } \\
\text { pembelajaran yang } \\
\text { dilakukan tanpa } \\
\text { tatap muka tapi } \\
\text { melalui platform } \\
\text { yang tersedia. }\end{array}$ & $\begin{array}{l}\text { 1. Kualitas konten } \\
2 \text {. Desain pembelajaran } \\
\text { 3. Assesment } \\
\text { 4. Teknologi }\end{array}$ & $\begin{array}{l}\text { Angket } \\
\text { dengan } \\
\text { skala Likert } \\
(1-5)\end{array}$ \\
\hline
\end{tabular}

Penggunaanmoodle
$\left(\mathrm{X}_{3}\right)$ adalah aktifitas
menggunakan paket
perangkat lunak
untuk membuat
pendidikan berbasis
internet sehingga
tercipta
pembelajaran
dinamis namun teap
menggunakan
orientasi objek

1. Kelengkapan materi

Angket

dengan

skala Likert yang digunakan

$(1-5)$

2. Kelengkapan isi media

3. Kejelasan bahasa pada soal

4. Kemudahan

pengoperasian

media

5. Ketertarikan pada

tampilan media

6. Video

pembelajaran

7. Rasa senang

menggunakan

media

8. Motivasi dalam belajar

9. Minat dalam

menggunakan

media pada

materi lain

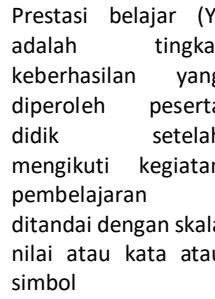

1. Mampu

menyelesaikan

tugas yang mudah

terlebih dahulu

Angket

dengan

skala Likert

$1-5$

2. Memilih

mengerjakan

tugas sesuai

kemampuan

3. Mampu

melakukan tugas

dalam bidang

berbeda

4. Mampu

menggunakan

pengalaman hidup

untuk mencapai

keberhasilan 


\begin{tabular}{|c|c|c|c|}
\hline \multirow[t]{6}{*}{ Dimensi } & & Indikator & Pengukuran \\
\hline & 5. & $\begin{array}{l}\text { Mampu menyikapi } \\
\text { situasi dan kondisi } \\
\text { beragam dalam } \\
\text { mencapai tujuan }\end{array}$ & \\
\hline & 6. & $\begin{array}{l}\text { Mendorong diri } \\
\text { untuk tetap } \\
\text { bertahan pada } \\
\text { setiap rintangan }\end{array}$ & \\
\hline & 7. & $\begin{array}{l}\text { Mampu } \\
\text { menghadapi } \\
\text { hambatan dalam } \\
\text { mencapai tujuan }\end{array}$ & \\
\hline & 8. & $\begin{array}{l}\text { Yakin akan semua } \\
\text { kemampuan diri } \\
\text { untuk } \\
\text { menyelesaikan } \\
\text { tugas }\end{array}$ & \\
\hline & 9. & $\begin{array}{l}\text { Tekun dalam } \\
\text { menyelesaikan } \\
\text { tugas }\end{array}$ & \\
\hline
\end{tabular}

\section{Kerangka Pemikiran}

Model penelitian merupakan serangkaian teori berupa gambaran sistematis dalam memberikan alternatif solusi dari masalah penelitian. Model penelitianprestasi belajar mahasiswa ditinjau dari penggunaan smartphone, sistem pembelajaran daring dan penggunaan moodle seperti gambar 3

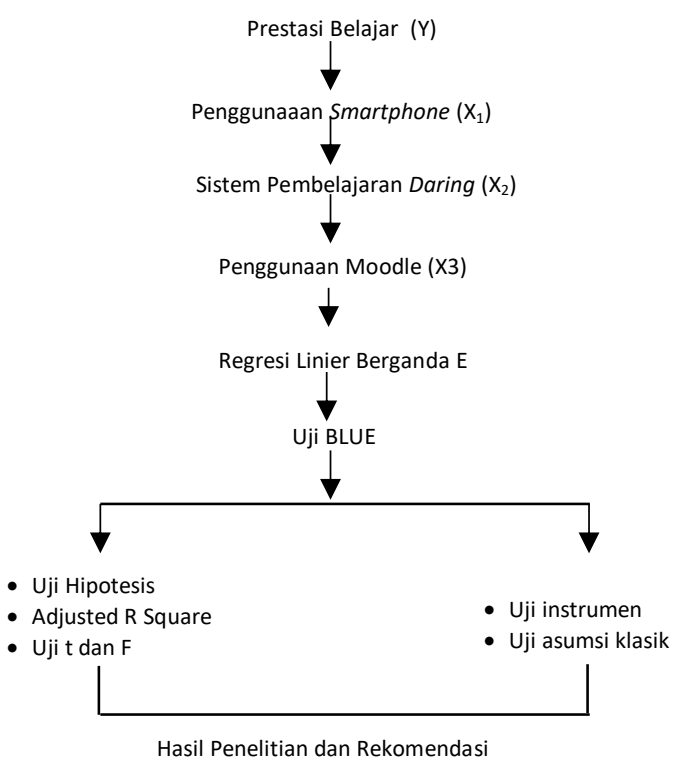

\section{Gambar 3}

\section{Model Penelitian}

Teknik pengumpulan data dengan field research dan library research. menggunakan angket penelitiN diukur menggunakan skala Likert

Uji instrumen terdiri dari uji normalitas, uji validitas dan uji reliabelitas (Gujarati, 2010). Uji normalitas menggunakan uji One Sample Kolmogorov-Smirnov(KS) pada tingkat signifikansi $5 \%$ Uji validitas menggunakan corrected item total correlation. Reliabelitas butir angket disebut reliabel jika nilai Cronbach's Alpha $\geq 0,60$.

Asumsi klasik model regresi linier menggunakan Best Linier Unbiased Estimation (BLUE) seperti multikolinieritas, autokorelasi dan heteroskedastisitas.

Pengaruh variabel bebas $\mathrm{X}_{1}$, $\mathrm{X}_{2}$ dan $\mathrm{X}_{3}$ terhadap $\mathrm{Y}$ menggunakan formula regresi linier berganda $\mathrm{Y}=\mathrm{a}+$ $\mathrm{b}_{1} \mathrm{X}_{1}+\mathrm{b}_{2} \mathrm{X}_{2}+\mathrm{b}_{3} \mathrm{X}_{3}+\mathrm{e} \operatorname{dimanaY}=$ prestasi belajar, $\mathrm{X}_{1}=$ penggunaan smartphone, $\mathrm{X}_{2}=$ sistem pembelajarandaring, $\quad \mathrm{X}_{3}=$ penggunaanmoodle, $\mathrm{a}=$ konstanta, $\mathrm{b}_{1}=$ koefisien regresi penggunaansmartphone, $\mathrm{b}_{2}=$ koefisien regresi sistem pembelajaran daring, $\mathrm{b}_{3}=$ penggunaaan moodledan e $=$ error term. Koefisien determinasi berguna untuk melihat proporsi variabel bebas terhadap variabel terikat nilainya $0-1$ (Gujarati, 2010). Jika $\mathrm{R}^{2} \leq 0$ maka antara variabel bebas dengan variabel terikat tidak terdapat hubungan dan jika $\mathrm{R}^{2} \leq 1$ maka antara variabel bebas dengan variabel terikat saling berhubungan. Dari hasil pengolahan data diperoleh $\mathrm{R}^{2}$ yang telah disesuaikan atau Adjusted $R$ Square. Nilai koefisien korelasi $\mathrm{R}$ digunakan untuk melihat korelasi antara variabel bebas dengan variabel terikat dengan kriteria (Sugiyono, 2015) sbb : $0.00-0.19$ (korelasi rendah sekali), $0.20-0.39$ (korelasi rendah tapi ada hubungan), $0.40-0.69$ (korelasi sedang), $0.70-0.89$ (korelasi tinggi) dan $0.90-1.00$ (korelasi tinggi sekali). 
Menurut (Sugiyono, 2015) uji t digunakan untuk menguji kebeartian koefisien regresi secara parsial dengan membandingkan $\mathrm{t}$ hitung dengan $\mathrm{t}$ tabel pada taraf signifikansi $\alpha=0.05$ dengan kriteria sbb: hipotesis diterima jika $\mathrm{t}$ hitung $\geq \mathrm{t}$ tabel atau $(\mathrm{P}<0.05)$ dan sebaliknya hipotesis ditolak jika t hitung $<\mathrm{t}$ tabel atau $(\mathrm{P}>0.05)$. Uji $\mathrm{F}$ digunakan untuk melihat pengaruh variabel bebas terhadap variabel terikat secara simultan dengan membandingkan $\mathrm{F}$ hitung dengan F tabel pada taraf signifikansi $\alpha=5 \%$ dengan kriteria sbb : hipotesis diterima jika $\mathrm{F}$ hitung $\geq \mathrm{F}$ tabel sebaliknya hipotesis ditolak jika $\mathrm{F}$ hitung $<\mathrm{F}$ tabel.

\section{HASIL DAN PEMBAHASAN}

Karakteristik responden didapat melalui angket diberikan kepada mahasiswa melalui google formseperti tabel 8.

Berdasarkan table 8 tentang karakteristik responden dapat disimpulkan sbb :

1. Mahasiswa FEB Universitas Dharma Andalas jenis kelamin perempuan paling banyak 76 orang (73.79\%) paling sedikit jenis kelamin laki-laki 27 orang $(26.21 \%)$. Dalam hal ini mahasiswa perempuan rata-rata lebih peduli dengan pelaksanaan sistem kuliah daring dibandingkan dengan mahasiswa laki-laki.

2. Mahasiswa FEB Universitas Dharma Andalas semuanya tinggal dengan orang tua 103 orang (100\%)selama sistem pembelajaran daringkarena kondisi covid 19 sehingga efisiensi biaya untuk kost, makan dan lain-lain.

3. Domisili mahasiswa FEB Universitas Dharma Andalas paling banyak 52 orang $(50.49 \%)$ tinggal di kota Padang dan paling sedikit 10 orang $(9.71 \%)$ tinggal di luar provinsi Sumtera Barat seperti Jambi, Bengkulu, Pekanbaru dan lain-lain.
4. Mahasiswa FEB Universitas Dharma Andalas menggunakan smartphonepaling banyak untuk buat tugas 47 orang $(50.51 \%)$ paling sedikit untuk lain-lain 21 orang (22.58\%).

5. Mahasiswa FEB Universitas Dharma Andalas paling banyak usia $20-25$ tahun 63 orang $(61.17 \%)$ paling sedikit usia $>25$ tahun 4 orang (3.88\%).

6. Pekerjaan orang tua mahasiswa FEB Universitas Dharma Andalaspaling banyak sebagai petani 31 orang $(30.10 \%)$ paling sedikit bekerja sebagai pegawai BUMN 1 orang $(0.97 \%)$.

7. Mahasiswa FEB Universitas Dharma Andalaspaling banyak sudah memiliki smartphone lebih dari 5 tahun sebanyak 33 orang $(32,01 \%)$ paling sedikit memilikinyaselama $2-3$ tahun 20 orang (19.42\%).

8. Mahasiswa FEB Universitas Andalas paling banyak menggunakan smartphone untuk kuliah daring lebih dari 4 jam sebanyak 69 orang $(66.99 \%)$ paling sedikit $3-4$ jam 15 orang (14.86\%).

Uji normalitas menggunakan One Sample KS pada taraf signifikansi $5 \%$ dengan ketentuan jika nilai statistik lebih besar dari tingkat signifikansi maka data berdistribusi normal seperti terlihat pada tabel 8 .

Tabel 8

Hasil Uji Normalitas

\begin{tabular}{lcc}
\hline \multicolumn{1}{c}{ Variabel } & Nilai Signifikansi & $\begin{array}{l}\text { Nilai } \\
\text { Statistik }\end{array}$ \\
\hline Penggunaan smartphone & 0.05 & 0.086 \\
Sistem pembelajarandaring & 0.05 & 0.074 \\
Penggunaan moodle & 0.05 & 0.067 \\
\hline Prestasi belajar & 0.05 & 0.073 \\
\hline
\end{tabular}

Sumber : Hasil Analisis SPSS, 2021

Berdasarkan tabel 8 nilai statistik penggunaaan smartphone, penggunaan 
moodle, sistem pembelajaran daring dan prestasi belajar masing-masingnya sebesar $0.086 ; 0.074 ; 0.067$ dan 0.073 sehingga dapat disimpulkan bahwa variabel penggunaan smartphone, sistem pembelajaran daring, penggunaan moodle dan prestasi belajar berdistribusi normal. Uji homogenitas dilakukan sebagai prasyarat dalam analisis independent sampel t test dan ANOVA dengan asumsi bahwa varian dari populasi sama. Kriteria pengujiannya jika nilai signifikansi lebih besar dari 0.05 maka varian dari dua atau lebih kelompok data sama. Hasil uji homogenitas dapat dilihat pada tabel 9 .

\section{Tabel 9}

Hasil Uji Homogenitas

\begin{tabular}{ccc}
\hline Variabel & Nilai Signifikansi & $\begin{array}{l}\text { Nilai } \\
\text { Statistik }\end{array}$ \\
\hline Penggunaan smartphone & 0.05 & 1.421 \\
Sistem pembelajarandaring & 0.05 & 1.395 \\
Penggunaan moodle & 0.05 & 1.373 \\
\hline Prestasi belajar & 0.05 & 1.367 \\
\hline
\end{tabular}

Sumber : Hasil Analisis SPSS, 2021

Berdasarkan tabel 9 nilai statistik penggunaan smartphone, sistem pembelajaran daring dan prestasi belajar masing-masingnya $1.421 ; 1.395 ; 1.373$ serta 1.367 sehingga dapat disimpulkan bahwa variabel penggunaan smartphone, sistem pembelajaran daring, penggunaan moodle dan prestasi belajar berdistribusi normal karena mempunyai variannya sama (nilai statistik)penggunaan smartphone, sistem pembelajaran daring, penggunaan moodle dan prestasi belajar masingmasingnya semakin kecil sehingga homogenitasnya semakin besar.
Uji instrumen reliabelitas memenuhi untuk semua variable penelitianseperti tabel10.

Tabel 10. Uji Reliabelitas

\begin{tabular}{ccccc}
\hline No. & Keterangan & $\begin{array}{c}\text { Cronbach } \\
\text { Alpha }\end{array}$ & $\begin{array}{c}r \\
\text { tabel }\end{array}$ & Keterangan \\
\hline 1. & $\begin{array}{c}\text { Penggunaan } \\
\text { smartphone }\end{array}$ & 0.873 & 0.60 & Reliabel \\
2. & $\begin{array}{c}\text { Sistem } \\
\text { pembelajaran } \\
\text { daring }\end{array}$ & 0.778 & 0.60 & Reliabel \\
3. Penggunaan \\
moodle & 0.640 & 0.60 & Reliabel \\
4. Prestasi belajar & 0.736 & 0.60 & Reliabel \\
\hline \multicolumn{4}{c}{ Sumber : Data Diolah, 2021 } \\
\hline
\end{tabular}

Uji multikolinieritas memenuhi untuk variabel penggunaan smartphone, sistem pembelajaran daring, penggunaan moodle dan prestasi belajar seperti tabel 11.

Tabel 11

\section{Uji Multikolinieritas}

\begin{tabular}{ccc}
\hline Model & \multicolumn{2}{c}{ Collinearity Statistics } \\
\cline { 2 - 3 } & Tolerance & VIF \\
\hline (Constant) & & \\
penggunaan_smartphone & .743 & 2.017 \\
sistem_pembelajaran_daring & .743 & 2.017 \\
penggunaan_moodle & .743 & 2.017 \\
\hline
\end{tabular}

Sumber : Data Diolah, 2021

Uji autokorelasi nilai DW 2.018

$>$ dU : 1.62337 tidak terdapat autokorelasi positif karena $2.018>1.62337$ dan nilai 4 - DW : 2.018 sebesar $1.880>\mathrm{dU}$ : 1.62337 tidak terdapat autokorelasi negatif karena $1.880>1.62337$ sehingga variabel penggunaan smartphone, sistem pembelajaran daring, penggunaan moodle dan prestasi belajar memenuhi asumsi autokorelasi.

Uji heteroskedastistashasil penelitian dapat dilihat pada tabel 12 . 
Tabel 12

Uji Heteroskedastisitas

\begin{tabular}{ccc}
\hline Model & $\mathrm{t}$ & Sig. \\
\hline (Constant) & 7.565 & .000 \\
Penggunaan smartphone & 3.735 & .001 \\
Sistem pemb.daring & 1.431 & .003 \\
Penggunaan moodle & 1.724 & .004 \\
\hline
\end{tabular}

Sumber : Data Diolah, 2021

Berdasarkan tabel 12 semua nilai variabel bebas penelitian nilai signifikan $>\quad 0.05$ sehingga tidak terjadi heteroskedastisitas.

Hasil analisis regresi linier berganda dapat dilihat pada tabel 13 .

Tabel 13.

\section{Coefficients $^{\mathrm{a}}$}

\begin{tabular}{|c|c|c|c|c|c|c|}
\hline & \multirow{2}{*}{ Model } & \multicolumn{2}{|c|}{$\begin{array}{l}\text { Unstandarized } \\
\text { Coefficients }\end{array}$} & $\begin{array}{l}\text { Standardized } \\
\text { Coefficients }\end{array}$ & \multirow{2}{*}{$\mathbf{t}$} & \multirow{2}{*}{ Sig. } \\
\hline & & B & $\begin{array}{l}\text { Std. } \\
\text { Error }\end{array}$ & Beta & & \\
\hline \multirow[t]{4}{*}{1} & (Constant) & 72.479 & 5.619 & & 7.565 & .000 \\
\hline & $\begin{array}{l}\text { Penggunaan } \\
\text { smartphone }\end{array}$ & 0.739 & .156 & .396 & 3.735 & .001 \\
\hline & $\begin{array}{c}\text { Sistem } \\
\text { pemb.daring }\end{array}$ & 0.256 & .089 & .135 & 1.431 & .003 \\
\hline & $\begin{array}{l}\text { Penggunaan } \\
\text { moodle }\end{array}$ & 0.437 & .0673 & .187 & 1.724 & .004 \\
\hline
\end{tabular}

a. Dependent Variable : Prestasi belajar

Berdasarkan tabel 12 didapat persamaan regresi linier berganda $\mathrm{Y}=72.479+$ $0.739 \mathrm{X} 1+0.256 \mathrm{X} 2+0.437 \mathrm{X} 3+\mathrm{e}$ dengan interpretasinya sebagai berikut :

1. $\mathrm{a}=72.479$ artinya jika tidak ada penggunaansmartphone, sistem pembelajaran daringdan penggunaanmoodle maka prestasi belajar mahasiswa FEB Universitas Dharma Andalas sebesar 72.479.

2. $\mathrm{b} 1=0.739$ artinya jika penggunaan smartphone naik 1 unit maka prestasi belajar mahasiswa FEB Universitas Dharma Andalas naik sebesar 0.739 dengan asumsi sistem pembelajaran daringtetap.

$3 . \mathrm{b} 2=0.256$ artinya jika pembelajarandaringnaik 1 unit maka prestasi belajar mahasiswa FEB Universitas Dharma Andalas naik sebesar 0.256 dengan asumsi penggunaansmartphonedan penggunaanmoodletetap.

4. $\mathrm{b} 3=0.437$ artinya jika penggunaanmoodle naik 1 unit maka prestasi belajar mahasiswa FEB Universitas Dharma Andalas naik sebesar 0.437 dengan asumsi penggunaan smartphone dan sistem pembelajarandaring tetap.

Tabel 13.

ANOVA ${ }^{\text {a }}$ Prestasi belajar

\begin{tabular}{|c|c|c|c|c|c|c|}
\hline \multicolumn{2}{|c|}{ Model } & \multirow{2}{*}{$\begin{array}{c}\begin{array}{c}\text { Sum of } \\
\text { Squares }\end{array} \\
232.128\end{array}$} & \multirow{2}{*}{$\frac{\mathrm{Df}}{2}$} & \multirow{2}{*}{$\begin{array}{c}\begin{array}{c}\text { Mean } \\
\text { Square }\end{array} \\
145.092\end{array}$} & \multirow{2}{*}{$\frac{F}{20.984}$} & \multirow{2}{*}{$\frac{\text { Sig. }}{.000^{\mathrm{b}}}$} \\
\hline 1 & Between & & & & & \\
\hline & Groups & & & & & \\
\hline & Within & 1473.117 & 66 & 88.219 & & \\
\hline & Groups & & & & & \\
\hline & Total & 1665.221 & 68 & & & \\
\hline
\end{tabular}

Uji hipotesis secara parsial (uji t) berdasarkan tabel 15 menunjukkan bahwa penggunaan smartphone, sistem pembelajaran daringdan penggunaan moodleberpengaruh positif signifikan terhadap prestasi belajar mahasiswa FEB Universitas Dharma Andalas karena $0.001<0.05 ; 0.003<0.05$ dan $0.004<$ 0.05 sehingga hipotesis penelitian diterima. Pengujian hipotesis secara simultan seperti tabel 16 menunjukkan $0.000<0.05$ sehingga penggunaan smartphone,pembelajaran daringdan penggunaan moodle berpengaruh positif signifikan terhadap prestasi belajar mahasiswa FEB Universitas Dharma 
Andalas. Penggunaan smartphone, sistem pembelajaran daring dan penggunaan moodle dengan prestasi belajar mahasiswa FEBUniversitas Dharma Andalas hubungannya sedang $(\mathrm{R}=$ 0.683) dan prestasi belajar mahasiswa FEB Universitas Dharma Andalas dijelaskan oleh penggunaan smartphone, sistem pembelajaran daringdan penggunaan moodle 0.576 sisanya 0.424 dijelaskan oleh faktor lain yang tidak termasuk dalam model penelitian seperti tabel 14.

Tabel 14.

\section{Model Summary}

Model Summary ${ }^{b}$

\begin{tabular}{lcccc}
\hline Model & R & R Square & $\begin{array}{c}\text { Adjusted R } \\
\text { Square }\end{array}$ & $\begin{array}{c}\text { Std. Error of } \\
\text { the Estimate }\end{array}$ \\
\hline 1 & $.683^{\text {a }}$ & .466 & .576 & 5.46933 \\
\hline $\begin{array}{l}\text { a.Predictor } \\
\text { pembelajaran daring dan } \\
\text { penggunaanmoodle } \\
\text { b.Dependent Variable : prestasi belajar }\end{array}$ & (constant) & Penggunaan & smartphone, sistem \\
\end{tabular}

\section{SIMPULAN}

Berdasarkan uraian hasil penelitian di atas dapat diambil kesimpulan sebagai berikut :

1. Berdasarkan uji hipotesis secara parsial penggunaan smartphone, sistem pembelajaran daringdan penggunaan moodleberpengaruh positif signifikan terhadap prestasi belajar mahasiswa FEB Universitas Dharma Andalas pada tingkat signifikansi 5\% karena 0.001 $<0.05 ; 0.003<0.05$ dan $0.004<0.05$

2. Berdasarkan uji hipotesis secara simultan penggunaan smartphone, sistem pembelajaran daringdan penggunaan smartphoneberpengaruh positif signifikan terhadap prestasi belajar mahasiswa FEB Universitas Dharma Andalas pada tingkat signifikansi $5 \%$ karena $0.000<0.05$
3. Hasil persamaan regresi linier berganda ditunjukkan oleh persamaan $\mathrm{Y}=72.479+0.739 \mathrm{X} 1+0.256 \mathrm{X} 2+$ $0.437 \mathrm{X} 3+\mathrm{e}$ artinya kontribusi penggunaan smartphone lebih besar pengaruhnya daripada sistem pembelajaran daring dan penggunaan moodle terhadap prestasi belajar mahasiswa FEB Universitas Dharma Andalas.

Berdasarkan hasil penelitian dapat diberikan beberapa saran sebagai berikut

1. Kepada peneliti selanjutnya disarankan untuk menambah variabel bebas lainnya yang akan mempengaruhi prestasi belajar mahasiswa FEB Universitas Dharma Andalas.

2. Perlu sosialisasi sistem pembelajaran daring menggunakanmoodle kepada mahasiswa untuk mencari solusi terkait kendala yang mungkin terjadi sehingga bisa diatasi.

3. Sampel penelitian agar dapat ditambah untuk ruang lingkup Universitas Dharma Andalas dengan 13 program studi agar hasil olahan data tidak bias.

\section{DAFTAR PUSTAKA}

Abdulhak, Ishak \& Darmawan, Deni. 2005. Teknologi Pendidikan. Bandung : PT Remaja Rosdakarya.

Albiladi, Waheeb and Khlood K. Alshareef. 2019. Blended Learning in English Teaching and Learning : A Review of the Current Literature. Journal of Language Teaching and Research. 10(2) : $232-238$.

Agus, Suprijono. 2010. Cooperative Learning. Yogyakarta : Pustaka Pelajar.

Anonim. 2014. Panduan Pengembangan Objek 
Pembelajaran. Jakarta :

Direktorat

Pembelajaran

dan

Kemahasiswaan.

Direktorat

Jenderal Pendidikan Tinggi,

Kementerian Pendidikan dan

Kebudayaan.

Arikunto, Suharsimi. 2010. Prosedur

Penelitian Suatu Pendekatan

Praktik. Jakarta : PT

Rineka Cipta.

Asmani, Jamal Ma'mur. 2011.Tips Efektif Pemanfaatan Teknologi Informasi danKomunikasi Dalam Dunia Pendidikan. Yogyakarta : Diva Press.

Bernard, Robert M, Eugene Borokhovski, David I. Waddington and David I. Pickup. 2019.

Twenty First Century Adaptive Teaching and Individualized Learning Operationalized as Spesific Blends of Student Centered Instructional Events : A Systematic Review and Meta Analysis. Journal Wiley Compbell Collaboration : 1 - 35 .

Cepik, Saban, Kemal Gonen and Mustafa Kemal Sazak. 2016. ELT Instructor's Attitudes

Towards the Use of Blended Learning in Tertiary Level English Language Programs. International Journal of Human Sciences. 13(1) : 1715 - 1730.

Damodar, Gujarati. 2010. Ekonometrika.Jakarta : Salemba Empat.

Darmalaksana, W. 2020. Atribut Pemimpin Abad 21. Fakultas Ushuluddin UIN Sunan Djati Bandung.

Despotovi, Z, M. Markovi, A.Bogdanovi, Z.Bara. 2012. Providing Adaptivity in Moodle LMS Course. Journal Educational Technology \& Society. 15(1) : $326-338$.
Dimyanti dan Mudjiyono. 2009. Belajar dan Pembelajaran. Jakarta : PT Rineka Cipta.

Djamarah, Syaiful Bahri. 1994. Prestasi Belajar dan Kompetensi Guru. Surabaya : Usaha Nasional.

Dougiamas, Martin. 2002. Thesis. Universitas Teknologi Curtin, Australia.

Edgar John Sintema. 2020. Effect of Covid 19 on the Performance of Grade 12 Students :

Implication for STEM Education. Eurasia Journal of Mathematics Science and

TechnologyEducation. 16(7) : $1-6$.

Edi, S Mulyanta. 2005. Kupas Tuntas Telepon Seluler Anda. Yogyakarta : Andi Offset.

Farahnak, L.R,Ehr.M.G, Torres,E.M dan Aarons,G.A. 2019. The Influencing of

Transformational Leadership and Leader Attitudes on Subordinate Attitudes and Implementation Successs. Journal of Leadership and Organization Studies.

Fuxin Yu. 2013. Mobile / Smartphone Use in Higher Education. Jakarta : Central Aksara.

Gleason, Benjamin and Christine Greenhow. 2017. Hybrid Learning in Higher Education :

The Potensial of Teaching and Learning with Robot-Mediated Communication. Online Learning Journal. 21(4) : 159 176.

He,W.,Xu,G and Kruck,S. 2014. Online IS Education for the 21 st Century. Journal of Information Systems Education.

Hollad,A.A. 2019. Effective Principles on Informal Online Learning Design : A Theory 
Building Metasynthesis of Quality Research. Journal Computer and Education.

Huda,M. Maseleno,A, Teh,K.S, Don,A.G, Basiro,Bjasmi,K, Ahmad,R. 2018. Understanding Modern Learning Environment (MLE) in Big Data Era. International Journal of

EmergingTechnologies in Learning (IJET).

Kuznetcova, Irina, Tzu Jung Lin and Michael Glassman. 2020. Teacher Present in a Different

Light: Authority Shift in MultiUser Virtual Environment. Journal Technology, Knowledge and Learning : $1-25$.

Marina, Anna dan Mellyna Eka Yan Fitri. 2016. Evaluasi Prestasi Belajar Mahasiswa

Terhadap Penggunaan Media Sosial Pada PTS Kota Padang. Jurnal Ekonomi dan Bisnis Dharma Andalas. 18(1).

Marina, Annna dan Nofri Yendra. 2021. Tinjauan Prestasi Belajar Mahasiswa Saat Pandemi

Covid 19 Di FEB Universitas Dharma Andalas. Jurnal Ekonomi dan Bisnis Dharma

Andalas. 23(1) .

Mihardjo,L,W. And Rukman,R.A. 2018. Does Digital Leadership Impact Directly or

Indirectly on Dinamic Capability : Case on Indonesia Telecomunication Industry in

Digital Transformation? The Journal of Social Sciences Research.

M.Fathurohman dan Sulistyorini. 2012. Belajar dan Pembelajaran. Yogyakarta : Teras.

Mulyono, Abdurrahman. 2003. Pendidikan Bagi Anak Berkesulitan Belajar. Jakarta: PT Rineka Cipta.
Munir. 2009. Pembelajaran Jarak Jauh Berbasis Teknologi Informasi dan Komunikasi.

Bandung : Alfabeta.

Mustofa, Iklil Mokhamad, Muhammad Chodzirin, Lina Sayekti. 2019. Formulasi Model

Perkuliahan Daring Sebagai Upaya Menekan Disparitas Kualitas Perguruan Tinggi

(Studi Terhadap Website ptitt.belajar.kemdikbud.go.id).

Walisongo Journal of

InformationTechnology. 1(2). 151 160.

Nesbit, J Belfer dan Leacock. 2004. Learning Object Review Instrument (LORI) User Manual. Retrieved Agust 19, 2017.

NHS Shared Learning. 2019. Quality Assurance Cheklists for Evaluating Learning Objects

and Online Courses.

Okaz, Abeer Ali. 2015. Integrating Blended Learning in Higher Education. Journal Procedia Social and Behavioral Sciences. (186) : $600-603$.

Onyenma, C.O dan Clara Nnoduka. 2020. Effect Blended Learning on Student's Retention

of Physics in Federal Colleges of Education in South East, Nigeria. Journal of

Education, Learning and Development. 8(1). Januari 2020 : $66-76$.

Palvia,S.,Aeron,P., Mahapatra, P.Parida,R., Rosner,R,. Sindhi,S. 2018. Online Education :

Worldwide Status, Challenges, Trends and Implications. Journal of Global Information Technology Management.

Panigrahi, R., Srivastava,P.R., and Sharma,D. 2018. Online Learning : Adoption Continuance 
and Learning Outcome - A Review of Literature. International Journal of Information Management.

Peraturan Menteri Pendidikan dan Kebudayaan No. 109 Tahun 2013 Tentang Penyelenggaraan Pembelajaran Jarak Jauh Pada Pendidikan Tinggi. Jakarta :Kemenristekdikti.

Prasojo, Lantip Diat \& Riyanto. 2011. Teknologi Informasi Pendidikan. Yogyakarta : Gava Media.

Puji Lestari, Yulita. 2020. Dampak Positif Pembelajaran Online Dalam Sistem Pendidikan Indonesia Pasca Pandemi Covid 19. Buletin Hukum dan Keadilan. 4(1) : $49-57$.

Ridwan dan Sunarto. 2009. Pengantar Statistika : Untuk Penelitian Pendidikan. Bandung :

Alfabeta.

Rice, William. 2011. Moodle 2.0 ELearning Course Development. Birmingham. Pack Publishing Ltd.

Robert, M.B.E dkk. 2019. Twenty First Century Adaptive Teaching and Individualized as Spesifific Blends of Student Centered Instructional Events : A Systematic Review and Meta Analysis. Journal Wilwy Compbell Collaboration. 17(3).

Rusman, Deni Kurniawan. 2012. Belajar dan Pembelajaran Berbasis Komputer. Bandung :

Alfabeta.

Ruman, Deni Kurniawan dan Cepi Riyana. 2011. Pembelajaran Berbasis Teknologi

Informasidan Komunikasi. Jakarta : PT Raja Grafindo.

Syah, Muhibbin. 2014. Psikologi Pendidikan Dengan Pendekatan Baru. Bandung : Remaja Rosdakarya.
Slameto. 2010. Belajar dan FaktorFaktor yang Mempengaruhi. Jakarta : PT Rineka Cipta.

Smith, A.W. and Freedman,D.O. 2020. Isolation, Quarantine Sosial Distancing and

Community Containment : Pivotal Role for Old Style Public Helath Measures in the

Novel Coronavirus (2019nCoV)Outbreak. Journal of Travel Medicine.

Sugiyono. 2015.Metode Penelitian Bisnis.Bandung : Alfa Beta.

Thigarajan, S, Semmel, D.S \& Semmel M.I. $1974 . \quad$ Instructional Development for Training Teachers of Expectional Chlidren. Minneapolis : Leadership Training Institute.

Tolsteneva,A.A, Gruzdeva,M.L., Katkova,O.V, Prokhorova, O.N, and Lagunova,M.V. 2019.

Organizational and Tecnical Conditions for the Implementation of Educational Programs of the University Using Open Online Courses of the National Platform for Open

Education. In Lecture Notes in Networks and System. Switzerland : Springer.

Undang-Undang No. 12 Tahun 2012 Tentang Pendidikan Tinggi. Jakarta : Kemenristekdikti.

Waheeb, S.A dan Khlood., K.A. 2019 Blended Learning in English Teaching and Learning :

A Review of the Current Literature. Journal of Languange Teaching and Researching.

10(2).

Williams, A. Birch,E and Hancock, P. 2012. Tke Impact of Online Lecture Recordings on

Student Performance. Australasian Journal of Educational Technology. 
Winkel, W.S. 1997. Psikologi

Pengajaran. Yogyakarta : Sketsa.

Internet

http://rahmandwi.blogspot.co.id/2014/04 /perkembangan-industri-teknologitelepon-selular html. Diakses pada 28 Mei 2020. http://alisadikinwear.wordpress.com/201 2/07/07/mobile-learning-mlearning-solusi-cerdas-

pembelajaran-terkini. Diakses pada 30 Mei 2020.

http://www.knowledge.scot.nhs.uk./medi a/4088630/quality assurance.checlists.pdf

http://www.transplantedgoose.net/gradst udies/edu892/LORI.5.pdf 